\title{
You have many accidents, you pay little, you have no accidents, you pay the same
}

\author{
Andrei-George Albulescu ${ }^{1}$, Ioan Popescu ${ }^{2}$, Anișoara Corăbieru ${ }^{1}$, Alin Marian Cazac $^{1}$, and \\ Mihai-Adrian Bernevig-Sava ${ }^{1, *}$ \\ 1، 'Gheorghe Asachi”, Technical University from Iasi, Dimitrie Mangeron Bd., no. 67, 700050 Iași, \\ România \\ ${ }^{2}$ Territorial Labor Inspectorate Neamt, Gh. Iacomi Str., 610150 Piatra Neamț, România
}

\begin{abstract}
Law no. 346/2002, the Law on insurance against accidents at work and occupational diseases, received the final blow. One by one, all the principles on which this law was built were repealed during the period 2002-2018 by various normative acts. The final blow was struck by the Emergency Ordinance no. 103 of December 14, 2017 for the amendment and supplementation of some normative acts in the field of social security and by the amendments made to Law no. 227/2015 on the Fiscal Code by the Emergency Ordinance no. 79 of November 8, 2017.
\end{abstract}

\section{General provisions}

To understand more easily the many changes this law underwent, we will address the amendments by going through each chapter of the law.

The insurance for accidents at work and occupational diseases is a person insurance, is part of the social security system, it is guaranteed by the state and implies specific relations that ensure the social protection of employees against the decrease or loss of their working capacity and their death due to accidents at work and occupational diseases (Article 1, Law $346 / 2002$, Law on insurance against accidents at work and occupational diseases).

The insurance for accidents at work and occupational diseases is substantiated by the following principles:

a) the insurance is compulsory for all those using manpower employed by an individual labour agreement;

b) the professional risk is assumed by those who benefit from the result of the work performed;

c) the establishment of insurance resources for accidents at work and occupational diseases from contributions borne by employers, according to the Law no. 227/2015 on the Fiscal Code, with subsequent amendments and additions,

(Art. 3 of Law 346/2002, the Law on Insurance against Accidents at Work and Occupational Diseases).

\footnotetext{
${ }^{*}$ Corresponding author: mihaibernevig@gmail.com
} 
A first inaccuracy in the law which remained uncorrected is that only the employers who have employees working under ILA (Individual Labour Agreement) have the obligation to insure. We will later find that there are also other categories that are compulsorily insured under the law.

The first major amendment of the law, namely the establishment of insurance resources, is no longer made by differentiated contributions depending on the level of risk borne by the employers or the natural persons concluding insurance contracts, but in a fixed amount according to the percentage established by the Law no. 227/2015 on the Fiscal Code.

\section{Insurance relatios and the insured risk}

The insurance relations resulting from this law are established between the employers and the insurer, for the insured persons (Art. 9 of Law 346/2002, the Law on Insurance against Accidents at Work and Occupational Diseases).

As far as insurance relations are concerned, we find another amendment that is profoundly discriminatory for those who work as self-employed persons and who would like to pay to become insured against the risk of injury or professional illness.

A whole range of individuals no longer have the possibility to become insured on the basis of an individual insurance agreement, such as

a) sole partner, partners, inactive partners or shareholders;

b) active partners, administrators or managers;

c) members of the family partnership;

d) persons authorized to carry out independent activities;

e) persons employed in international institutions;

f) property owners and/or tenants of agricultural and forestry areas;

g) persons carrying out agricultural activities within individual households or private activities in the field of forestry;

h) members of agricultural partnerships or of other forms of association in agriculture;

i) other interested persons, carrying out their activity on the basis of legal relationships other than those mentioned above.

It can also be found that all the provisions regarding professional insurance associations established for this purpose, per fields of activity of the national economy, were removed from the law. These had specific responsibilities to insure against accidents at work and occupational diseases, in the capacity of service providers.

The specific responsibilities to insure against accidents at work and occupational diseases are taken over by territorial houses of pensions.

Professional insurance associations operated on the basis of their own Articles of Association, in compliance with the provisions of the Government Ordinance no. 26/2000 on associations and foundations.

The provision on the recovery of debts in case the insurance contribution for accidents at work and occupational diseases was not paid by fault of the employer or of the person insured on the basis of an individual insurance agreement, was eliminated by amending art. 13 of the law.

In such cases, the cost of insurance services provided by the insurer should have been recovered from the employer or from the person insured on the basis of an individual insurance agreement. It seems that the Romanian state has enough funds and no longer needs money. 


\section{Insurance objective}

The insurance for accidents at work and occupational diseases has the following objectives:

a) prevention of accidents at work and occupational diseases;

b) the medical and socio-professional rehabilitation of insured persons, victims of accidents at work and occupational diseases, as well as the recovery of their work capacity;

c) the provision of long-term and short-term cash benefits in the form of allowances and other benefits, under the conditions provided by the present law.

(Art. 16, Law 346/2002, the Law on Insurance against Accidents at Work and Occupational Diseases).

Unfortunately, upon considering the content of the law, we find that although the main objective of the law is the prevention of accidents at work and occupational diseases, the current form of the law refers more to the payment of the benefits generated by accidents at work and occupational diseases.

\section{Benefits and insurance services for accidents at work and occupational diseases}

The persons ensured within the insurance system for accidents at work and occupational diseases are entitled to the following benefits and services:

a) medical rehabilitation and the recovery of the capacity to work;

b) rehabilitation and change of career path;

c) allowance for temporary incapacity to work;

d) allowance for temporary changing the workplace and allowance for reduced working time;

e) compensation for impairment of integrity;

f) damages in case of death;

g) reimbursement of expenses;

h) invalidity pension, following an accident at work or an occupational disease;

i) survivor's pension in the event of death as a result of an accident at work or of an occupational disease.

(Art. 18, Law 346/2002, the Law on Insurance against Accidents at Work and Occupational Diseases).

We have a favourable change here, by explicitly introducing the benefits mentioned on letters $\mathrm{h}$ ) and $\mathrm{k}$ ).

Another amendment made to the detriment of employers refers to the recovery by the employer of the amounts paid as leave allowance, as a result of an accident at work or occupational disease.

The old form of the law set a 90-day deadline for the insurer to reimburse the amounts to the employer. The current form of the law no longer provides a deadline.

\subsection{Benefits and services for investigation, medical diagnosis, medical rehabilitation and recovery of the capacity to work}

The amendment of art. 21 confirms that the counter value of the tickets for the hydropathic treatment of those who are undergoing temporary incapacity to work due to an accident at work or an occupational disease, are covered from the amounts provided for insurance against accidents at work and occupational diseases in the state social insurance budget and not entirely from the insurance contributions for accidents at work and occupational diseases. The state allocates from the contributions as much as it considers necessary. 


\subsection{Benefits and services for rehabilitation and change of career path}

This subchapter was not amended.

\subsection{Allowance for temporary incapacity to work}

The amendment of art. 34 establishes that the allowance for temporary incapacity to work in case of an accident at work or an occupational disease is covered from the amounts provided for the insurance against accidents at work and occupational diseases in the state social insurance budget and not entirely from the insurance contributions for accidents at work and occupational diseases.

By the amendment of art. 35, the period of granting the allowance for temporary incapacity to work is increased from 180 days to 183 days within a year, calculated as of the first day of sick leave.

\subsection{Allowance for temporary changing the workplace and allowance for reduced working time}

This subchapter was not amended.

\subsection{Compensation for impairment of integrity}

The amendment of art. 42 eliminates the possibility for persons receiving a third degree disability pension and who are entitled to have a working program reduced to 4 hours a day, to benefit from compensation for impairment of integrity and who, as a result of accidents at work or occupational diseases, have remained with permanent injuries that produce deficiencies and reduce the capacity to work to $20-50 \%$.

The amendment of art. 44, paragraph 2, significantly reduces the amount of the compensation for impairment of integrity, which is determined depending on the severity of the lesion, within the maximum limit of 12 basic gross minimum wages per country, as opposed to the maximum limit of 12 medium gross wages per country provided for before the amendment.

\subsection{Damages in case of death}

This subchapter was not amended.

\subsection{Reimbursement of expenses}

The amendments of this subchapter do not adversely affect the employer and the insured person.

\section{Communication and identification of accidents at work and occupational diseases}

By the amendment of art. 52, paragraph 1, on determining the rights to insurance, the insurer shall have access to and use the investigation report and the work accident registration form - FIAM, drawn up in compliance with the law, as opposed to the old provision referring only to the investigation report. Unfortunately, in many cases, it is not possible for the employer to draw up the work accident registration form - FIAM. 
By the amendment of art. 52, paragraphs 2 and 3, the insurer waives the right to verify the manner in which the investigation was carried out, to directly coordinate the investigation of the accident, to conduct an own investigation or to assess the investigation dossier drawn up by the employer's committee and to decide on the nature of the accident which resulted in temporary incapacity to work. It keeps the right to challenge these documents and to ask the competent authorities to review them in case they find errors or inaccuracies in the documents.

Subsequently, by the amendment of art. 53, the insurance rights provided for by this law are granted for accidents at work only on the basis of the event investigation report, amendment made by Law 177/2018.

\section{Prevention of accidents at work and occupational diseases}

The employers are responsible for ensuring safety and health at work. (art. 55).

By the amendment of art. 62, paragraph 1, the insurer releases itself from the responsibility to coordinate the activity of prevention of accidents at work and occupational diseases at a national level and assumes only the role of supporting the employers in their activity of prevention of accidents at work and occupational diseases.

Also, by the amendment of the paragraph, CNPP (The National House of Public Pensions) transfers the prevention activities to the territorial pension houses, although the latter do not have the necessary financial independence,

Article 63 of the law establishes and reduces the attributions of the insurer's technical staff, that carries out activities for the prevention of accidents at work and occupational diseases, as well as those of the medical staff specialized in occupational medicine. All these under the conditions in which this staff does not exist, not even today, 16 years after the law came into existence. CJP (The County Houses of Pensions) have 1to 3 people reassigned to the respective services, and they are mostly economists and legal advisers.

The insurer's technical staff, that carries out activities for the prevention of accidents at work and occupational diseases, as well as the medical staff specialized in occupational medicine, have the following attributions:

a) participate in the establishment of national priority prevention programs, by identifying situations with a high risk of accidents at work and occupational diseases;

b) provide consultancy on the measures and means to prevent accidents at work and occupational diseases;

c) make proposals to specialized research institutes, for carrying out and financing studies and analyses in order to substantiate national priority prevention measures;

d) provide employers with technical assistance for the elaboration of prevention instructions;

e) investigate accidents resulting in temporary incapacity to work and determine their nature in accordance with the provisions of this law; [repealed]

f) keep records of accidents at work and occupational diseases;

g) recommend prevention measures and control their application;

h) propose to the insurer the increases or reduction of the contribution to stimulate the prevention activity; [repealed]

i) establish prevention programs based on the concrete situations identified in the workplaces;

j) advise employers on occupational safety and health.

The medical staff specialized in occupational medicine has also attributions related to the detection, investigation and determination of the professional nature of the disease.

Obviously, this low number staff can only deal with keeping record of accidents at work and occupational diseases and reimbursing the expenses they generate. 
In the exercise of its duties, the specialized technical and medical staff is authorized (Art. 64):

a) to have free access to the employers' headquarters or the workplaces they've organized and to be accompanied by the persons designated by the employer;

b) to benefit from the findings of the investigation of accidents at work or occupational diseases, carried out by the competent state authorities;

c) to notify the state authorities when it becomes aware of violations of the current legislation on labour protection;

d) to propose to employers the dimensioning of the labour protection departments according to the risks present at the workplaces;

e) to review the results of the medical examinations performed upon hiring and those of the periodical medical examinations of the insured persons;

f) to request any information and documents necessary for the fulfilment of the tasks related to the prevention of accidents at work and occupational diseases;

g) to recommend to the employer measures for preventing accidents at work and occupational diseases.

In carrying out their activity, the staff in charge of the prevention of accidents at work and occupational diseases is obliged to keep the confidentiality of the data received from the employer regarding the organizational, technological and manufacturing aspects of the controlled unit, as well as of the other data provided by the competent state authorities or by any other body or person involved in the prevention activity, as well as the confidentiality of employees' medical data (Art. 65).

The insurer's expenditures for the activity of preventing accidents at work and occupational diseases are registered in a separate analytical account. The maximum amount allocated for this purpose may not exceed $10 \%$ of the amounts collected as contribution throughout a calendar year (Art. 66).

\section{Organization of the insurance system for accidents at work and occupational diseases}

Article 68 of the law establishes and reduces the attributions of the CNPP (The National House of Pensions) with regard to carrying out the activity of insuring against accidents at work and occupational diseases:

a) coordinates and controls the activity in this field, carried out by the territorial pension houses;

b) it can co-finance programs within projects for the prevention of accidents at work and occupational diseases;

c) applies measures to improve the benefits and insurance services 'for accidents at work and occupational diseases;

d) elaborates the criteria and methodology underlying the calculation of the insurance contribution for work accidents and occupational diseases; [repealed]

e) guides and controls the activity of preventing accidents at work and occupational diseases;

f) controls the manner of granting the benefits and insurance services provided for by this law, for accidents at work and occupational diseases;

g) controls the manner in which increases or reductions in the contribution are granted in order to stimulate the prevention activity; [repealed]

h) it may organize, at a national level, upon the proposal of the Territorial Houses of Pensions, the activity of functional recovery, prosthetics, reorientation and change in career path, for the professional reintegration of the persons who have suffered accidents at work and occupational diseases; [repealed] 
i) organizes the records of insured cases, as well as of the insurance costs at a national level;

j) issues and withdraws the operation authorization of professional insurance associations; [repealed]

k) it can finance, at a national level, applied research-studies to develop-solutions, devices and methods to prevent accidents at work and occupational diseases; [repealed]

l) it can organize the instruction, training and improvement of the personnel in the field of insurance against accidents at work and occupational diseases;

m) makes proposals on the expenditure to be financed from the income resulting from insurance contributions for accidents at work and oceupational diseases; [repealed]

n) supervises the execution of the income and expenses implied by the activity of insurance against accidents at work and occupational diseases and submits quarterly and annual reports on the budget execution, to the Minister of Labour, Family, Social Protection and the Elderly;

o) coordinates the occupational safety and health management activity; [repealed]

p) verifies the manner in which work accidents followed by temporary incapacity to work are investigated, by directly participating in the investigation or by analysing the supporting documents, as appropriate; [repealed]

r) determines the professional nature of the accident followed by temporary incapacity to work. [repealed]

The repeal of art. 75, 76, 77, 78 and 79 eliminates the possibility for employers and selfemployed persons to establish professional insurance associations at the level of the fields of activity of the national economy.

\section{Insurance contributions for accidents at work and occupational diseases}

The repeal of art. $80,81,82,83,84,85,86,87,88,89$ and 90 cancels completely the provisions of this chapter.

\section{The income and expenditure of insurance for accidents at work and occupational diseases}

The amendments of art. 91 stipulate that the income of the insurance system for accidents at work and occupational diseases is constituted from the labour insurance contribution (CAM), in accordance with the provisions of Law no. 227/2015 on the Fiscal Code.

The income provided for under art. 91 is intended exclusively for financing the benefits and insurance services provided for by this law for accidents at work and occupational diseases, as well as for financing the organization and operation of the insurance system regulated by this law.

The intended use of the expenses for the benefits and insurance services for accidents at work and occupational diseases is established by the provisions of art. 93 of the law:

a) medical rehabilitation and recovery of the capacity to work;

b) rehabilitation and change in career path;

c) specialized investigations and laboratory analyses necessary to establish the professional character of the diseases;

d) allowance for temporary incapacity to work;

e) allowance for temporary changing the workplace and allowance for reduced working time;

f) compensation for impairment of integrity; 
g) damages in case of death;

h) reimbursement of expenses;

i) the activity of preventing accidents at work and occupational diseases;

j) medical services provided within health units having a legal personality and occupational diseases/occupational medicine sections/departments or within an outpatient system through the occupational medicine offices within the structure of hospitals, for the treatment of occupational diseases and accidents at work.

k) the payment of invalidity pensions, following an accident at work or an occupational disease;

i) the payment of survivor's pensions, in the event of death as a result of an accident at work or of an occupational disease.

The repeal of art. 96 of the law, transfers the resources of the initial fund for the operation of the insurance system, registered on December 31, 2003, such as they were created according to Law no. 632/2002 on the State Social Insurance Budget for 2003, from the CNPP budget, into the consolidated state budget. As a result of this transfer, these funds can be spent by the state in any area and not only for financing benefits and insurance services for accidents at work and occupational diseases.

\section{Legal liability}

The amendments of art. 99, 100, 101 and 102 are generated by the amendments made to previous articles of the law and increase the amount of fines.

\section{The jurisdiction of insurance against accidents at work and occupational diseases}

The amendments of art. 103, 104 and 107 are generated by the amendments of the applicable legislation, respectively Law no. 287/2009 on the Civil Code, republished, as amended, and Law no. 134/2010 on the Civil Procedure Code, republished, as subsequently amended.

\section{Transitional and final provisions}

The amendments in this last chapter are generated by the amendments made to previous articles in the law.

Before moving on to the conclusions, we will show the manner in which, ever since 2002, the contribution rates owed by employers have been lowered according to the risk class, without any justification linked to the actual decrease in the number of work accidents and/or professional diseases. These reductions were generated only by populist goals, just to show that the social contributions owed by employers were reduced.

1. Contribution rates owed by employers on the basis of the risk class are set from $0.5 \%$ to $4 \%$, applied to the total monthly gross salary fund (Art. 101 of Law 346/2002 on Insurance against Accidents at Work and Occupational Diseases).

2. Contribution rates owed by employers on the basis of the risk class are set from $0.4 \%$ to $3.6 \%$, applied to the total monthly gross salary fund (amended by art. 24 of LAW no. 487 date December 27, 2006).

3. Contribution rates owed by employers on the basis of the risk class are set from $0.4 \%$ to $2 \%$, applied to the amount of the gross monthly income (art. 18 of Law no. 387 dated December 31, 2007). 
4. Contribution rates owed by employers on the basis of the risk class are set from $0.15 \%$ to $0.85 \%$, applied to the amount of the gross monthly income (art. 20 of Law no. 19 dated February 26, 2009).

5. Contribution rates owed by employers are calculated as a percentage of $5 \%$ of the $2.25 \%$ percentage, referred to as Labour Insurance Contribution (CAM), see art. $220^{3}$ and art. $220^{4}(4)$ of Law no. $227 / 2015$ on the Fiscal Code. The monthly basis for the calculation of the labour insurance contribution is represented by the sum of the gross income from salaries and similar income, in the country and abroad, see art. $220^{4}(1)$ of Law no. 227/2015 on the Fiscal Code.

\section{Conclusions}

The fundamental principle of the law, bonus-malus, has been completely cancelled. The term bonus-malus is used by insurers in insurance agreements and offers alternatively a bonus (bonus) or a penalty (malus). It stipulates that if you have many accidents at work and/or occupational diseases, you pay an increasingly higher risk rate, and if you do not have accidents at work and/or occupational diseases, you pay the lowest risk rate. In most European countries, the legislation on accidents at work and occupational diseases is based on this principle.

The risk classes according to which all Romanian companies were classified according to the risk class of the company's main activity, have disappeared.

The notion of risk rate has disappeared, and today all companies pay an equal contribution that is calculated as $5 \%$ out of the $2.25 \%$ referred to as Labour Insurance Contribution (CAM).

The state has practically confiscated all the financial excess resulting from contributions for insurance against accidents at work or occupational diseases, paid by employers throughout this period. It is not known what has been done with the excess accumulated over the years through the payment of the risk rates. [5]

Any financial motivation for Romanian companies to invest in the prevention and protection activity in order to reduce the number of work accidents or occupational diseases, as disappeared. The financial motivation for Romanian companies to refurbish, to use new technologies and non-hazardous raw materials for workers, has also disappeared. Regardless of the registered number of accidents at work or occupational diseases, the insurance contribution is equal

A very unpleasant and discriminatory phenomenon has emerged, namely the companies that do not register work accidents or occupational illnesses, are increasingly assisting by the payment of their insurance contributions for accidents at work or occupational illnesses, those who report work accidents or occupational diseases (the principle of solidarity).

The activity of preventing accidents at work and occupational diseases, which should have been carried out by the insurer, The National House of Public Pensions (CNPP), respectively by the County Pension Houses, is now the responsibility of the employer.

Since the establishment and until today, the insurer has never presented a detailed report on the amounts spent in relation to the prevention activity.

Risk assessment and the risk assessors were significantly affected by the disappearance of risk classes.

\section{References}

1. Law no. 346 of 5 June 2002 on insurance against accidents at work and occupational diseases

2. LAW no. 287 of 17 July 2009 on the Civil Code - Republished 
3. Law no. 134 of 1 July 2010 on the Code of Civil Procedure - Republished

4. Law no. 227 of 8 September 2015 regarding Fiscal Code

5. DARABONT, D.C., BEJINARIU, C., IONITA, I., BERNEVIG-SAVA, M.-A., BACIU, C., BACIU, E.-R., Considerations on Improving Occupational Health and Safety Performance (Environ. Eng. Manag. J. 17, 2711-2718, 2018) 